\title{
INFLUENCE OF DIFFERENT TEMPERATURE LEVELS ON THE DATE OF FULL BLOOM OF PEACH VARIETIES IN SUBTROPICAL CLIMATE ${ }^{1}$
}

\author{
AUGUSTO CARLOS POLA², EMILIO DELLA BRUNA ${ }^{3}$, \\ ÁLVARO JOSÉ BACK ${ }^{4}$, ALEXSANDER LUÍS MORETO 5
}

\begin{abstract}
The dormancy dynamics of temperate fruit tree species is complex and highly variable according to genotype and environment. Due to this variability, many phenological models of cold units have not been suitable for subtropical climatic conditions in southern Brazil. The aim of this study was to evaluate the influence of air temperature on the peach dormancy in Urussanga-SC. For this purpose, the correlations between the date of full bloom of sixteen peach varieties and the total hours in which the temperatures remain in certain thermal levels were evaluated. Two groups of varieties with highly differentiated responses to temperature in various times were identified. In the first group, consisting of ten varieties, the beginning of significant influence $(\mathrm{p}<0.05)$ of temperatures on the date of full bloom occurred as earlier, in February. In this group, temperatures between 16 and $22{ }^{\circ} \mathrm{C}$ accumulated from March to June were those that most contributed to the flowering advance. In the second group, the beginning of the significant influence of temperatures occurred later in April. In this group, the accumulated high temperatures from early April to late May anticipated the full bloom, but from May 25 , temperatures below $10^{\circ} \mathrm{C}$ were responsible for this advance. This behavior differs from traditional phenological models that consider a sequential cold and heat requirement in the resting phase. The results obtained indicate the possibility of an alternating or parallel influence of different temperature levels on dormancy.
\end{abstract}

Index terms: Prunus persica, dormancy, temperature, statistical method.

\section{INFLUÊNCIA DE DIFERENTES NÍVEIS TÉRMICOS SOBRE A DATA DA PLENA FLORAÇÃO DE VARIEDADES DE PESSEGUEIRO EM CLIMA SUBTROPICAL}

\begin{abstract}
RESUMO - A dinâmica da dormência de espécies frutíferas de clima temperado é complexa e muito variável de acordo com o genótipo e o ambiente. Em razão desta variabilidade, muitos modelos fenológicos de unidades de frio não se têm mostrado adequados para as condições climáticas subtropicais brasileiras. Objetivou-se com o presente trabalho avaliar como a temperatura do ar influencia a dormência do pessegueiro em UrussangaSC. Para isto, foram avaliadas as correlações entre as datas de plena floração de dezesseis variedades de pessegueiro e o total de horas em que as temperaturas permanecem em determinados níveis térmicos. Foram identificados dois grupos de variedades com respostas altamente diferenciadas às temperaturas, em diversos períodos. No primeiro grupo, constituído por dez variedades, o início da influência significativa $(p<0,05)$ das temperaturas sobre a data de plena floração ocorreu mais precocemente, em fevereiro. Neste grupo, as temperaturas entre 16 e $25^{\circ} \mathrm{C}$, acumuladas de março a junho, foram as que mais contribuíram para a antecipação da floração. No segundo grupo, o início da influência significativa das temperaturas ocorreu mais tardiamente, em abril. Neste grupo, as altas temperaturas acumuladas do início de abril ao final de maio anteciparam a plena floração, mas a partir de $20 / 05$ foram as temperaturas abaixo de $10^{\circ} \mathrm{C}$ as responsáveis por esta antecipação. Este comportamento difere dos modelos fenológicos tradicionais, que consideram uma exigência sequencial de frio e de calor nesta fase de repouso hibernal. Os resultados obtidos indicam a possibilidade de que ocorra uma influência alternada e/ou paralela de diferentes níveis térmicos sobre a dormência.
\end{abstract}

Termos para indexação: Prunus persica, dormência, temperatura, método estatístico.

'(Paper 154-15). Received June 11,2015. Accepted: November 18, 2015

${ }^{2}$ Agronomist, MSc, researcher at Epagri. Email: pola@epagri.sc.gov.br

${ }^{3}$ Agronomist, MSc, researcher at Epagri. Email: emilio@epagri.sc.gov.br

${ }^{4}$ Agronomist, $\mathrm{PhD}$, researcher at Epagri. Email: ajb@epagri.sc.gov.br

${ }^{5}$ Agronomist, PhD, researcher at Epagri. Email: alexsandermoreto@epagri.sc.gov.br 


\section{INTRODUCTION}

Temperate fruits during the dormancy period have reduced metabolic activities and do not show visible growth. At this stage, meristems are protected from adverse climatic phenomena such as low temperatures, including negative ones, for a relatively long period. Dormancy is a complex phenomenon with differentiated physiological and biochemical characteristics between genotypes and environments. The air temperature is considered the main climatic factor involved in the phenological variations observed in this phase.

Dormancy is commonly subdivided into three different stages: paradormancy, endodormancy and ecodormancy (HRUY et al., 2013). In the paradormancy stage, the biochemical signal for growth control originates outside the affected structure. This biochemical sign may be caused by environmental factors (e.g., photoperiod) or not (e.g., apical dominance of a terminal bud over lateral bud). In endodormancy, the perception of environmental or endogenous factors leading to growth control occurs only within the affected structure (bud). In ecodormancy, environmental factors such as extreme temperatures, lack of water or nutrients restrict development.

There are several models of cold units used for different species around the world, most of which consider a sequential pattern of thermal needs during dormancy. In general, these models consider the accumulation of temperatures between 0.0 and 19.0 ${ }^{\circ} \mathrm{C}$ to overcome endodormancy (KAMYUN et al., 2014). Later, in ecodormancy, in a sequential model, plants need a heat accumulation to reach the anthesis. The most common phenological models have been developed for temperate climate conditions, where autumn and winter climates are more regular and should be adjusted to Southern Brazil conditions (ANZANELLO et al., 2014).

The understanding of the dormancy dynamics of a particular commercial cultivar in its environment is important because it allows a planning that makes the application of diverse cultural practices such as pruning, thinning, fertilization and application of products for the breakdown of dormancy more effective. In addition, the definition of the cold and heat requirements of a variety is an important tool for genetic improvement and agro-climatic zoning works, among others.

The use of statistical models is an option to help in understanding the behavior of temperate fruit tree species in subtropical or tropical climate conditions. The correlations of air temperature with the date of full bloom, even if not significant, allow knowing the trends and the relative effect of different thermal levels on certain physiological stages or dormancy periods. Thus, the aim of the present work was to carry out statistical studies with peach varieties to help understand the behavior of this species under the climatic conditions of Urussanga$\mathrm{SC}$. The results may help in the future development of models that allow predicting the moment of occurrence of specific physiological stages, thus enabling the characterization of the climatic needs of fruit varieties.

\section{MATERIAL AND METHODS}

The phenological data used came from a collection composed of peach tree selections resulting from genetic improvement located in Urussanga, state of Santa Catarina, Brazil $\left(28^{\circ} 31\right.$ ' $\mathrm{S}$, and $49^{\circ} 19^{\prime} \mathrm{W}, 49 \mathrm{~m}$ asl). Sixteen selections considered to be adapted to the climate of the region were evaluated. This collection was formed by five plants in sequence of each variety, and for the average phenological records, three central plants were used. The dates of full bloom were recorded when plants were with approximately $50 \%$ of flowers open. Phenological data recorded from 2006 to 2010 were used. The site of the collection is about $200 \mathrm{~m}$ from the meteorological station.

The selections, grafted on Okinawa rootstock, were cultivated with spacing of $6 \mathrm{~m}$ between rows and $5 \mathrm{~m}$ between plants in a Typic Hapludalf of granitic origin. The climate of the region is subtropical humid, with hot summer and no defined dry season ( $\mathrm{Cfa}$, according to the Köppen classification). The average annual temperature is $19.4^{\circ} \mathrm{C}$, with maximum average temperature of $25.9^{\circ} \mathrm{C}$ and minimum of $14.2^{\circ} \mathrm{C}$. The total annual rainfall is $1624.0 \mathrm{~mm}$, and is normally well distributed throughout the year. The hours of cold below $7.2^{\circ} \mathrm{C}$ occur from May to September with an average annual total of 234 hours.

The average daily air temperature data $\left(T_{a}\right)$ were collected at the conventional meteorological station of Urussanga-SC, where $T_{a}=\left(T_{\max }+T_{\min }\right.$ $\left.+T_{9}+2 T_{2}\right) / 5$, where $T_{\max }$ is the maximum daily temperature, $T_{\min }$ is the daily minimum temperature, and $T_{9}$ and $T_{2}$ are temperatures from 9:00 a.m. to $9: 00$ p.m. respectively. For the calculation of hourly temperatures, a linear variation between the occurrence of these four daily temperatures daily recorded was considered and the time of extreme temperatures (6:00 a.m. and 3:00 p.m.) was considered fixed. Hourly temperatures were estimated by simple linear interpolation. The number 
of hours at which the air temperature $(\mathrm{t})$ remained in certain thermal ranges was calculated using spreadsheet and conditional functions. The thermal ranges used were: $\mathrm{t} \leq 7.0^{\circ} \mathrm{C} ; 7.0<\mathrm{t} \leq 13.0 ; 13.0<\mathrm{t}$ $\leq 16.0 ; \ldots ; \mathrm{T}>25.0^{\circ} \mathrm{C}$.

\section{RESULTS AND DISCUSSION}

The sixteen peach tree varieties presented different influences from temperatures on the dates of full bloom, with divergent correlations and opposite signs in certain periods. For this reason, varieties were divided into two groups to facilitate evaluations. Group 1 is presented in Figure 1, where the correlations between the date of full bloom and the mean ten-day temperatures of ten selections can be observed. Group 2, composed of six selections, is presented in Figure 2. Positive correlations indicate that the higher the average temperature in a given period, the later the full bloom date occurs. One difference that is easily visualized in both groups is that the selections of group 1 (Figure 1) showed greater influence of high temperatures on the flowering anticipation in the beginning of February and the month of May.

The varieties of group 1 presented positive correlations in the months of March and April, indicating that in these two months, the higher the average temperature, the later the full bloom date occurs (Figure 1). However, for varieties of group 2 , correlations were predominantly negative in these two months, with the increase in average temperature anticipating full blooming (Figure 2). In the second group, it was observed that the beginning of the influence of temperatures on the anticipation of full bloom occurred from the end of March.

Figure 3 shows the correlations between total accumulated hours and the full flowering date of S139 access in the period from March to July. This access was classified as a variety of early thermal influence of group 1. In this type of chart, negative correlations indicate that the higher the number of hours in a given temperature range, the earlier the full bloom date. It was observed in the graph that temperatures between 16 and $22{ }^{\circ} \mathrm{C}$ are responsible for the advance of flowering, on average, in the periods from February 21 to July 31 . The high temperatures $\left(>25^{\circ} \mathrm{C}\right)$ were the main contributors, on average, to the delay in the flowering of this variety. Thus, in the months of March and April, the high temperatures (> 22 and $>25^{\circ} \mathrm{C}$ ) are the main responsible for the delay in flowering. From April, temperatures between 16 and $22{ }^{\circ} \mathrm{C}$ will exert a greater and gradual influence in anticipating full bloom.
Varieties of group 1 behaved similarly to variety S139 shown in Figure 3. It was observed that in the other selections of this group, the date of full bloom is significantly advanced $(p<0.05)$ due to temperatures between 16 and $22{ }^{\circ} \mathrm{C}$ and between 16 and $25{ }^{\circ} \mathrm{C}$ occurring from March to June, and that lower or higher temperatures in relation to these during this period may delay the date of full bloom. The analysis of graphs and correlations has shown that, in general, the temperatures of the month of July did not contribute significantly to variations observed in these dates.

The evolution of the negative correlations of temperatures accumulated between 16 and $22{ }^{\circ} \mathrm{C}$ in Figure 3 shows that from the beginning of May, variety S139 may already be in the ecodormancy phase. It was observed that the increase of the response intensity to this temperature range is gradual. In this figure, temperatures before May that anticipate the date of full blooming are between 13 and $22^{\circ} \mathrm{C}$. Pereira et al. (2012) observed more intense endodormancy at the beginning of May in peach trees in the municipality of Fazenda Rio Grande-PR.

Some studies have indicated that intermediate temperatures may be the most efficient for early blooming or budding in varieties with lower cold requirement. Chavarria et al. (2009) tested temperatures of 5,10 and $15{ }^{\circ} \mathrm{C}$ in peach trees in Pelotas-RS using branches harvested in May and June and concluded that the temperature of $15{ }^{\circ} \mathrm{C}$ was the one that promoted the earliest development of flowers. Hawerroth et al. (2013) found that this temperature is the most efficient in an early variety of apple trees under controlled temperature conditions $\left(5,10\right.$ and $\left.15{ }^{\circ} \mathrm{C}\right)$. Under subtropical climate conditions, some peach cultivars break their dormancy very easily, and this may be due to superficial dormancy or lack of endodormancy (CHAVARRIA et al., 2009; HRUY et al., 2013 SCARIOTTO et al., 2013).

Figure 4 refers to Mondardo cultivar, which in this work is classified as a late thermal influence variety of group 2. It was observed in the graph that the high temperatures accumulated from the beginning of April to the end of May (mainly above $25^{\circ} \mathrm{C}$ ) have anticipated the date of full bloom and that from May 20 , temperatures below $10^{\circ} \mathrm{C}$ are those that influence the anticipation of flowering (with $\mathrm{R}>$ $0.88, \mathrm{p}<0.05$ ). On average, from early April to July 20 , temperatures between 10 and $19^{\circ} \mathrm{C}$ were the main responsible for the delay in the date of full bloom. Therefore, higher temperatures anticipate flowering until the end of May and from there, they gradually contribute to its delay. 
Observing the behavior of group 2 varieties, an opposite result in relation to many models used worldwide was observed, which consider a sequential influence of temperatures on dormancy. In these traditional models mainly developed for temperate climatic conditions, plants firstly require an accumulation of cold in endodormancy and later heat in ecodormancy. Figure 4 shows that in the period immediately preceding full bloom, theoretically a phase of ecodormancy, lower temperatures anticipate flowering when they should delay it.

For group 1 varieties, in which low temperatures would contribute to the anticipation of full flowering in a supposed endodormancy period and higher temperatures, in sequence, would contribute to its anticipation in ecodormancy, a sequential model could be admitted. But for group 2 varieties, traditional cold / heat sequential models could not be considered.

Campoy et al. (2011), in their work with controlled temperatures in a variety of low cold requirement for apricot trees, have suggested that after a partial amount of cold has been accumulated, cold and heat would act in a parallel way, that is, cold and heat requirements would not be subsequent events, but would occur at the same time. Harrington et al. (2010) also suggested that both functions occur at the same time. Therefore, a parallel and / or alternating influence of the different thermal levels on dormancy should not be disregarded in evaluations or development of agrometeorological models for peach tree in mild climate conditions.

When considering the possibility of alternating and parallel influences of temperature on the date of full bloom, we can also consider that flowering buds of group 2 varieties were in an endodormancy state in the months of June and July. Some group 2 varieties showed in these two months a significant negative correlation $(\mathrm{p}<0.05)$ of low temperatures for the anticipation of the date of full bloom and a positive correlation of higher temperatures for its delay. In the region of Urussanga-SC, in general, the senescence and natural fall of the leaves occurs from March to June, varying among genotypes and years. Early defoliations tend to anticipate the date of full bloom in peach due to a decrease in dormancy depth, but the influence of this factor on the bud development depends on the cultivar (GARIGLIO et al., 2012). According to Atkinson et al. (2013), endodormancy actually only occurs after foliar abscission. It could thus be inferred that, as the leaves fall under the influence of decreasing temperature and day length, buds would enter into a state of endodormancy (more or less superficial depending on the variety) and accumulate the heat needed for anthesis during this period (i.e., influence of heat acting in parallel with cold), but this hypothesis can only be proved in further studies.

Due to the highly differentiated responses of the date of full bloom to temperatures presented so far, it is possible to state that each variety, or groups of varieties, would require the development of specific models of cold units or hours. It has been observed that temperatures between 10 and $13{ }^{\circ} \mathrm{C}$ or between 13 and $16^{\circ} \mathrm{C}$, which occur from April to July, could significantly delay full bloom, contrary to what many classic models have found (LUEDELING, 2012).

Due to the large variation in responses to temperatures that different peach varieties can present at a particular site during dormancy, we suggest the use of preliminary statistical studies to assist in the planning and evaluation of results of future projects with biological or biochemical tests. Of course, these preliminary studies would depend on the availability of phenological and meteorological data. 


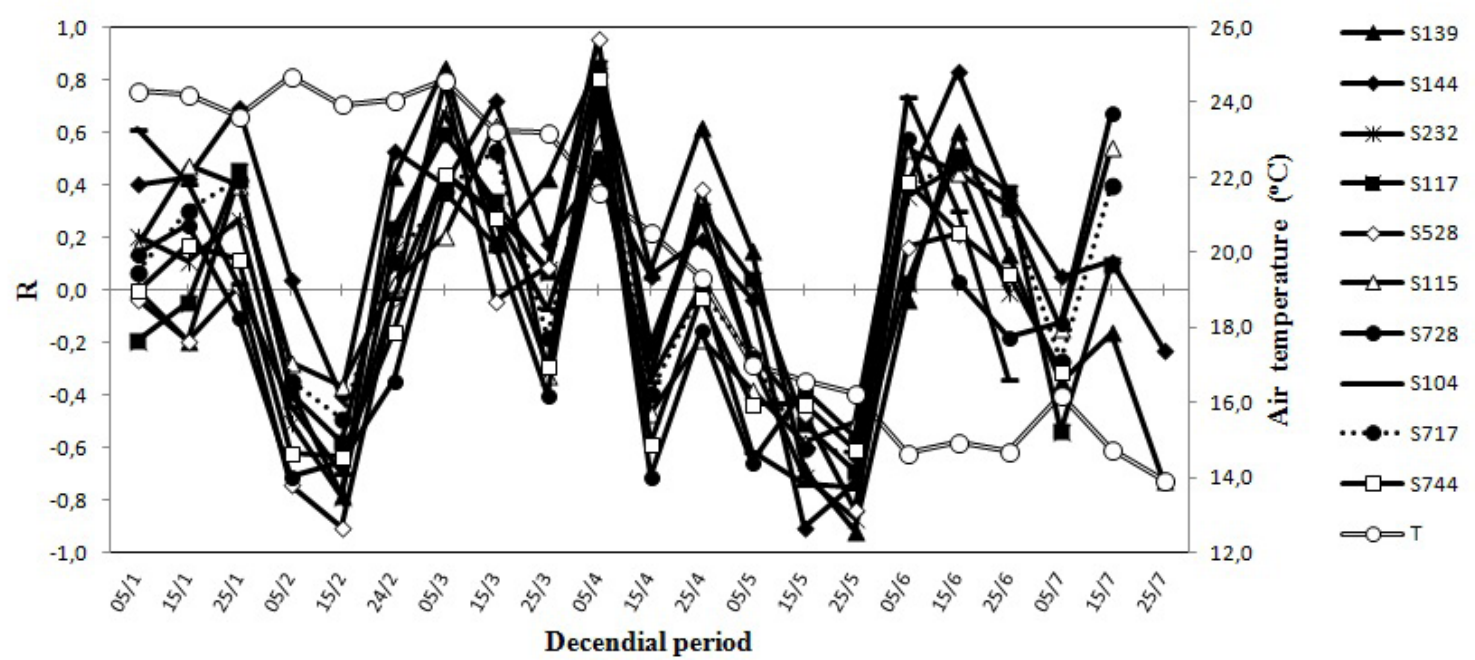

FIGURE 1 - Correlations (R) between decendial average temperatures and date of full bloom of ten peach tree selections (S139, S144, ..., S744) belonging to group 1; T is the average decendial temperature $\left({ }^{\circ} \mathrm{C}\right)$. Urussanga-SC, 2006 to 2010.

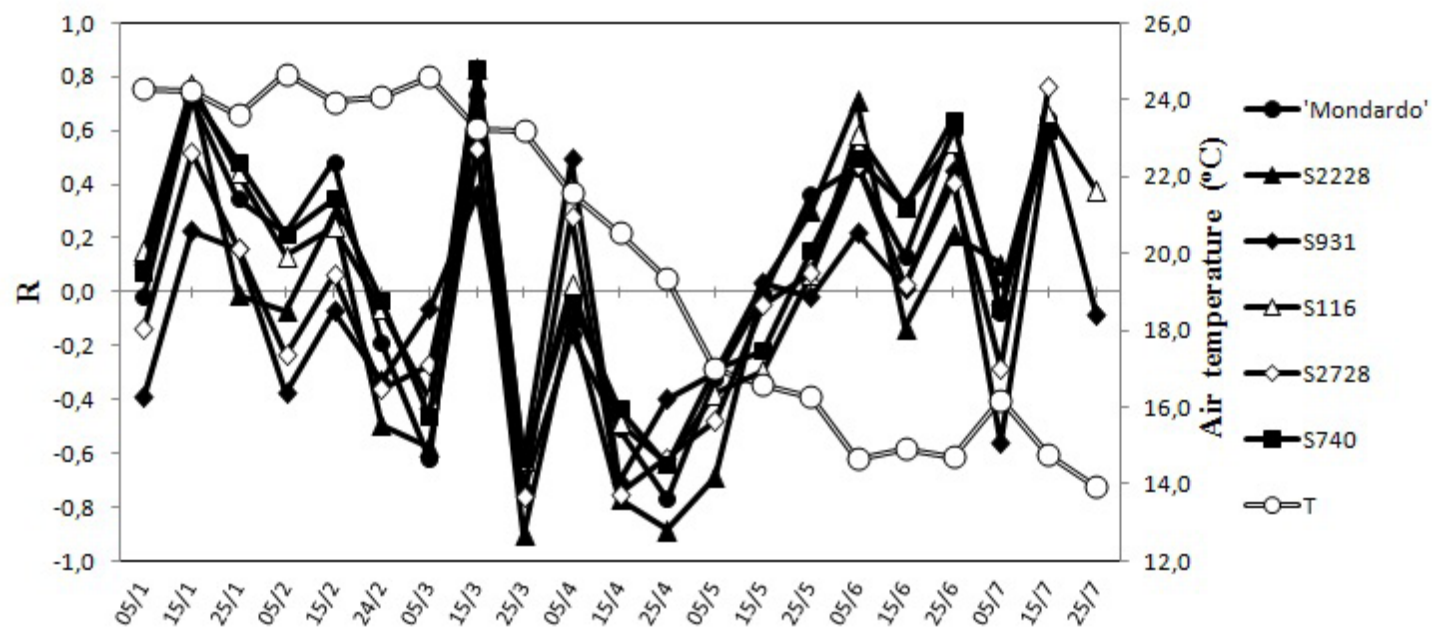

Decendial period

FIGURE 2 - Correlations (R) between decendial average temperatures and date of full flowering of six of peach tree selections ( 'Mondardo', S2228, ..., S740) belonging to group 2; T is the average decendial temperature $\left({ }^{\circ} \mathrm{C}\right)$. Urussanga-SC, 2006 to 2010. 


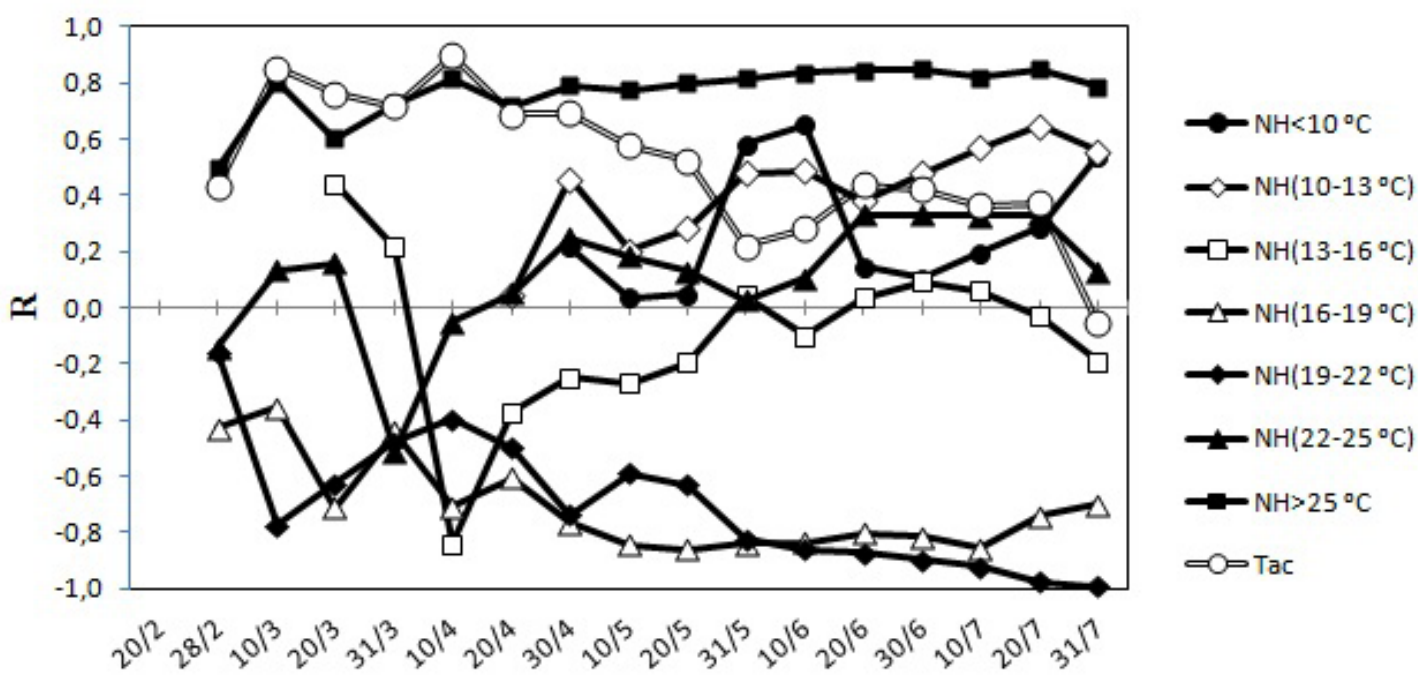

Date

FIGURE 3 - Correlations (R) between number of hours of accumulated temperatures (NH) and date of full blooming of peach variety S139. Tac refers to the correlations between average accumulated temperatures and date of full bloom. Urussanga-SC, 2006 to 2010.
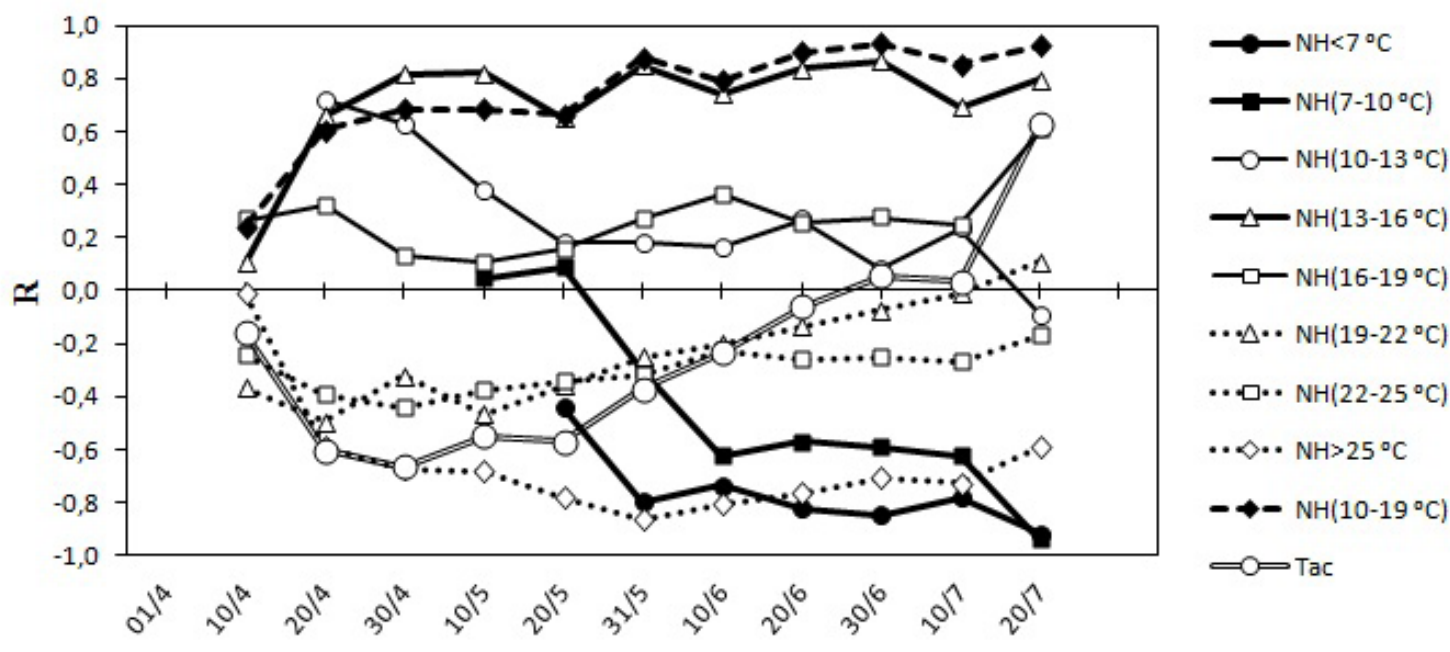

Date

FIGURE 4 - Correlations (R) between number of hours of accumulated temperatures (NH) and date of full blooming of Mondardo peach variety. Tac refers to the average accumulated temperatures. Urussanga-SC, 2006 to 2010. 


\section{CONCLUSIONS}

Traditional sequential cold / heat requirement models are not applicable for some peach varieties grown in Urussanga-SC.

The variations observed in the dates of full bloom may be due to an alternating and / or parallel influence of different thermal levels on dormancy.

\section{REFERENCES}

ANZANELLO, R.; FIALHO, F.B.; SANTOS, H.P.; BERGAMASCHI, H; MARODIN, G.A.B. Bud dormancy in apple trees after thermal fluctuations. Pesquisa Agropecuária Brasileira, Brasília, DF, v.49, n.6, p.457-464, 2014.

ATKINSON, C.J.; BRENNAN, R.M.; JONES, H.G. Declining chilling and its impact on temperate perennial crops. Environmental and Experimental Botany, Amsterdam, v.91, p.48-62, 2013.

CAMPOY, J.A.; RUIZ, D.; EGEA, J.; REES, D.J.G.; CELTON, J.M.; MARTINEZ-GOMEZ, P. Inheritance of flowering time in apricot (Prunus armeniana L.) and analysis of linked quantitative trait loci (QTLs) using simple sequence repeat (SSR) markers. Plant Molecular Biology Reporter, New York, v.29, n.2, p.404-410, 2011.

CHAVARRIA, G.; HERTER, F.G.; RASEIRA, M.C.B; RODRIGUES, A.C.; REISSER, C.; SILVA, J.B. Mild temperatures on bud breaking dormancy in peaches. Ciência Rural, Santa Maria, v.39, n.7, p.2016-2021, 2009.

GARIGLIO, N.; MARCELA, W.; MARIEL, P.; CARLOS, B.; DAMIAN, C.; AMPARO, M.F.; CARLOS, M.; CARMINA, R.; MANUEL, A. Chemicals applied in fall and defoliation on dormancy evolution and release in low-chill peach 'Flordaking'. Agrociencia Uruguay, Montevideo, v.16, n.2, p.49-59, 2012.

HARRINGTON, C.A.; GOULD, P.J.; CLAIR, J.B.S. Modeling the effects of winter environment on dormancy release of Douglas-fir. Forest Ecology and Management, Amsterdam, v.259, n.4, p.798808, 2010.
HAWERROTH, F.J.; HERTER, F.G.; PETRI, J.L.; MARAFON, A.C.; LEONETTI, F. Evaluation of winter temperatures on apple budbreak using grafted twigs. Revista Brasileira de Fruticultura, Jaboticabal, v.35, n.3, p.713-721, 2013.

HRUY, G.; TEGENBOS, J.; PETRE, R.; DECKERS, T.;TEKLEBIRHAN, Y.;BAUER, H.; GEBREHIWOT, K.; RAES, D.; DECKERS, J.; KEULEMANS, J. Studies on mode of expression of apple (Malus x domestica Borkh.) bud dormancy under tropical and temperate climatic conditions. Journal of Agricultural Science and Technology B, Tehan, v.3, p.503-516, 2013.

KAMYUN, N.; PICHAKUM, A.; BUNWONG, K.; TIENSUWAN, M.; MOORE, E.J. Development of chill unit calculation for peach 'Jade' fruit trees grown in northern Thailand. Acta Horticulturae, The Hague, v.1059, p.147-154, 2014.

LUEDELING, E. Climate change impacts on winter chill for temperate fruit and nut production: A review. Scientia Horticulturae, Amsterdam, v.144, p.218229, 2012.

PEREIRA, G.P.; CARVALHO, R.I.N.; BIASI, L.A.; ZANETTE, F. Dinâmica da dormência de pessegueiro, ameixeira e caquizeiro na Fazenda Rio Grande, PR. Revista Brasileira de Ciências Agrárias, Recife, v.7, p.820-825, 2012.

SCARIOTTO, S.; CITADIN, I.; RASEIRA, M.C.B.; SACHET, M.R.; PENSO, G.A. Adaptability and stability of 34 peach genotypes for leafing under Brazilian subtropical conditions. Scientia Horticulturae, Amsterdam, v.155, p.111-117, 2013. 